\title{
Fouling Polychaetes in Tanjung Priok Port of Jakarta, Indonesia
}

\author{
Hadiyanto Hadiyanto ${ }^{1, *}$ \\ ${ }^{1}$ Research Center for Oceanography - Indonesian Institute of Sciences, Jalan Pasir Putih I No. 1, Ancol Timur, Jakarta Utara 14430, \\ Indonesia \\ *Corresponding author: hadiyanto@lipi.go.id
}

\section{KEYWORDS}

Fouling polychaetes

Jakarta

Java

Native species

Tanjung Priok Port

\begin{abstract}
Fouling polychaetes in Tanjung Priok Port, Jakarta and their status were studied in order to update the list of marine alien species in Indonesia. Polychaetes were collected using six PVC panels that were submerged at a depth of $0.5 \mathrm{~m}$ over three months in Jakarta Bay. Polychaetes were identified to the lowest taxon possible based on characteristics of external morphology. The geographical distribution of identified polychaetes was then determined based on taxonomic literature in order to justify whether they were native or alien species for Indonesian waters. Twelve fouling polychaetes belonging to nine families are reported here. Of these, nine species (i.e., Chrysopetalum debilis, Eunice hirschi, Ceratonereis mirabilis, Leonnates decipiens, Polyophthalmus pictus, Eulalia (Eumida) sanguinea, Lepidonotus tenuisetosus, Hydroides elegans, and Polydora ciliata) were native species, while three other taxa (i.e., Namanereis sp., Hypsicomus sp. 1, and Hypsicomus sp. 2) were undetermined.
\end{abstract}

(c) The Author(s) 2018. This article is distributed under a Creative Commons Attribution-ShareAlike 4.0 International license.

\section{INTRODUCTION}

Biofouling of artificial structures has been studied intensively in various topics, such as community composition (Ramadan et al. 2006; Yan et al. 2006; Wilhelmsson and Malm 2008; Swami and Udhayakumar 2010; Yan et al. 2009; Babu et al. 2011) and population dynamics of single species (Bastida et al. 1971; Toonen and Pawlik 1996; Hamer et al. 2001). Fouling organisms mainly consist of macroalgae and invertebrates (Railkin 2004), with polychaetes often as the most abundant group in term of individual numbers (Stachowitsch et al. 2002) and species diversity (Relini et al. 1998a, b; Swami and Udhayakumar 2010). They settle on hardbottom substrates after around 2-3 weeks as a consequence of the presence of the biofilm and the roughness created by the irregular microbial colonies (Almeida et al. 2007).

Some fouling polychaetes are known as alien and invasive species in many regions, such as Ficopomatus enigmaticus in the Northern Adriatic Sea (Bonaca 2001) and Uruguay (Muniz et al. 2005), Branchiomma luctuosum in the Valencia Port of Spain (El Haddad 2007) and Branchiomma bairdi in the Mediterranean Sea (Arias et al. 2013). Marine alien and invasive species usually influence socio-economic and ecological aspects of the new location, including human health, national and local economies, marine ecosystems, and marine ecological communities (Bax et al. 2003; Davis 2009). Therefore, the alien species must be identified and studied to understand their biology, which is useful for environmental managers to control or eradicate them (Ricciardi and Rasmussen 1998).

Marine alien species can be transferred through international shipping, e.g., via hull fouling and ballast water (Ruiz et al. 1997). Hence international ports are common locations surveyed by scientists to detect the introduction of marine alien species (Williams et al. 1988; Hutchings and Glasby 2004; Ranasinghe et al. 2005; David et al. 2007; Drake and Lodge 2007; Arias et al. 2013). Tanjung Priok Port of Jakarta is the largest and the busiest international port in Indonesia. This port was visited by 3,415 units of oceangoing ships and 9,237 units of inter-island ship in 2012 (PT. Pelabuhan Indonesia II 2013). Thus, Tanjung Priok Port of Jakarta is a good representative site for studying the introduction of marine alien species in Indonesia.

An understanding of fouling polychaetes and their status in Tanjung Priok Port of Jakarta is important because our knowledge of alien marine species in Indonesia is limited. Alien aquatic species in Indonesia consist of 88 species, but only seven species are related to the marine environment. One macroalgal species inhabits coastal waters (i.e., Eucheuma cottonii), while the others (prawns and fish) inhabit mixed habitats, ranging from fresh, brackish and coastal waters (i.e. Anguilla anguilla, Salmo salar, Litopenaeus vannamei, Penaeus stylirostris, Poecilia latipinna and Poecilia sphenops). All of them are introduced via aquaculture activities (Kawaroe and Sunuddin 2010). The sponge Desmapsamma anchorata and the octocoral Carijoa riisei are also indicated as an alien species in Indonesian waters that are introduced through international shipping (Calcinai et al. 2004).

This study aims to identify fouling polychaetes in Tanjung Priok Port, Jakarta, Indonesia. Their status, whether native or alien species, would be also analysed in order to update the list of marine alien species in Indonesia.

\section{MATERIALS AND METHODS}

The study was conducted in the docking port area of Tanjung Priok Port, Jakarta (06 $06^{\circ} 00^{\prime \prime S}$ and 106 $\left.53^{\prime} 00^{\prime \prime E}\right)$ from November 2011 to January 2012. During this period, 
the salinity in the area ranged from 25-32 psu and the surface temperature ranged from $22-30^{\circ} \mathrm{C}$.

Polychaete samples were collected using six PVC panels of $10 \times 20 \mathrm{~cm}$ that were fully submerged in a vertical position about $0.5 \mathrm{~m}$ below the surface. Three panels were sampled monthly, which were replaced with three new ones for the next sampling, and the other panels were sampled after every three months. Panels were fixed in $10 \%$ formaldehyde seawater solution for a few days, carefully scraped, sieved through $0.5 \mathrm{~mm}$ mesh, and preserved in $96 \%$ alcohol.

Polychaetes were identified to the lowest possible taxon based on external morphology. The species name was then confirmed based on the previous studies conducted within Indonesian waters (Horst 1912, 1917; 1924; Mesnil and Fauvel 1939; Caullery 1944; Pillai 1965; AlHakim and Glasby 2004; Aguado et al. 2008) to determine whether the polychaete species collected in this study are new records. The status of polychaetes, whether native or alien species, was then determined based on their geographical distribution from taxonomic reports. The specimen lots (POL 73-99) were deposited in Research Center for Oceanography, Indonesian Institute of Sciences, Jakarta, Indonesia (abbreviated RCO-LIPI).

\section{RESULTS}

In total, 12 fouling polychaete species were identified. Nine species of fouling polychaetes are indicated as new records in Indonesian waters, but they are indicated as native species. The status of polychaetes identified only to genus level was not determined (Table 1).

\subsection{Taxonomy of fouling polychaetes}

\subsubsection{Family Chrysopetalidae Ehlers, 1864}

\section{Chrysopetalum debilis (Grube, 1855) (Figure 1A-F)} Paleanotus debilis in Day 1967: 117; fig. 2.1.g-k.

Material examined. 1 specimen (POL 73), Tanjung Priok Port, Jakarta, 19th November 2011, Hadiyanto; 1 specimen (POL 74), Tanjung Priok Port, Jakarta, 17th January 2012, Hadiyanto Diagnosis. Body is about $7 \mathrm{~mm}$, and completely covered by paleae (Figure 1A). Prostomium presents with four obvious eyes. There is a nuchal fold behind the prostomium (Figure 1B). Paleae attach on the mid-dorsal of parapodia (Figure 1C). Each palea is asymmetrical, jagged, and has around 6-7 ribs (Figure 1D, E). Neurosetae are heterogomph unidentate falcigers (Figure 1F).

Habitat. Intertidal zone (Day 1967) and artificial hardbottom.

Table 1. Fouling polychaetes collected from Tanjung Priok Port of Jakarta and their status.

\begin{tabular}{lll}
\hline Species & Family & Status \\
\hline Chrysopetalum debilis* & Chrysopetalidae & Native \\
Eunice hirschi* & Eunicidae & Native \\
Ceratonereis mirabilis* & Nereididae & Native \\
Namanereis sp. & Nereididae & Undetermined \\
Leonnates decipiens* $^{*}$ & Nereididae & Native \\
Polyophthalmus pictus* & Opheliidae & Native \\
Eulalia (Eumida) sanguinea* & Phyllodocidae & Native \\
Lepidonotus tenuisetosus* & Polynoidae & Native \\
Hypsicomus sp.1 & Sabellidae & Undetermined \\
Hypsicomus sp.2 & Sabellidae & Undetermined \\
Hydroides elegans* & Serpulidae & Native \\
Polydora ciliata* & Spionidae & Native
\end{tabular}

Note: * indicates new record in Indonesian waters
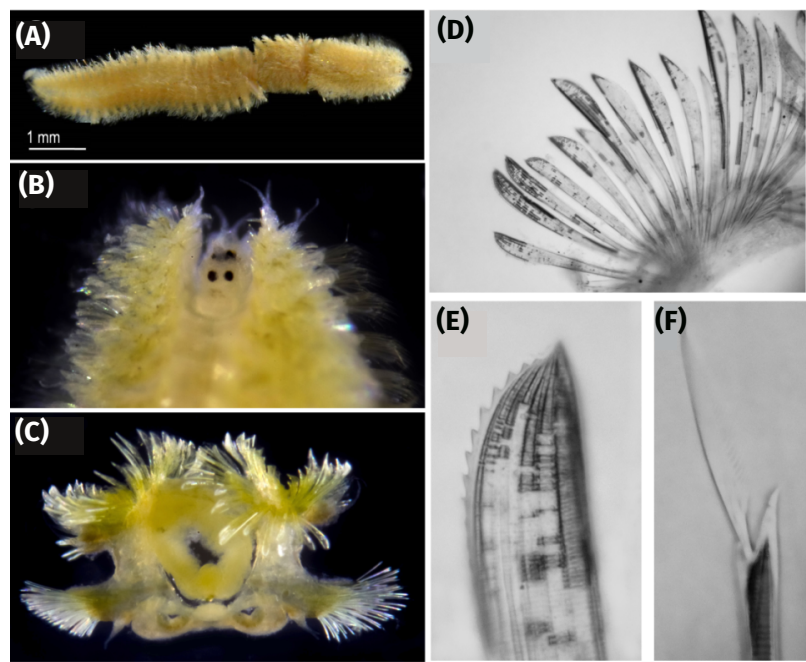

Figure 1. Chrysopetalum debilis (Grube, 1855). (A) entire worm (broken in the middle); (B) anterior end showed nuchal fold behind the prostomium; (C) middle parapodia; (D) paleae; (E) the tip of palea; (F) neurosetae.

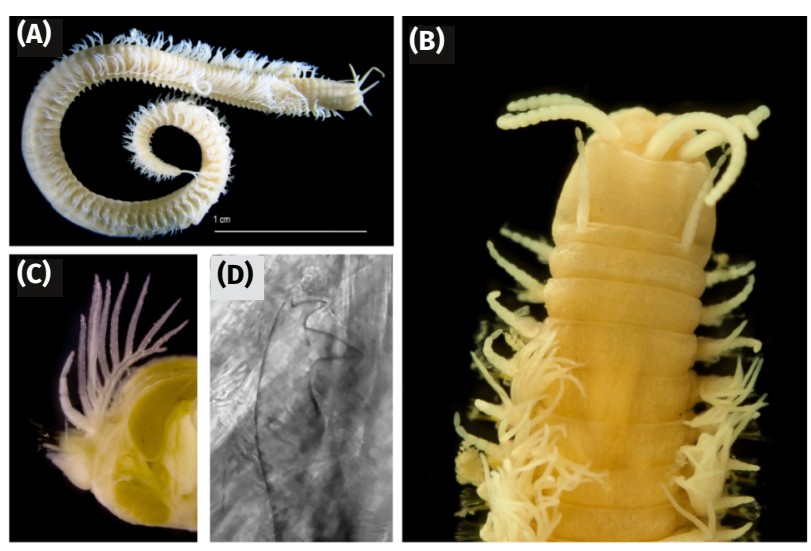

Figure 2. Eunice hirschi Fauchald, 1992. (A) entire worm; (B) anterior end; (C) branchiae; (D) subacicular hook.

Distribution. North Atlantic, Mediterranean, Red Sea, tropical Indian Ocean (Day 1967)

\subsubsection{Family Eunicidae Berthold, 1827}

Eunice hirschi Fauchald 1992 (Figure 2A-D)

Eunice hirschi Fauchald 1992: 171-173; fig. 56a-i.

Material examined. 5 specimens (POL 75), Tanjung Priok Port, Jakarta, $17^{\text {th }}$ January 2012, Hadiyanto.

Diagnosis. The length of entire body is about $5 \mathrm{~cm}$ with branchiae that present on more than $65 \%$ of the total number of setigers (Figure 2A). Five occipital antennae and tentacular cirri present, and all ceratostyle articulations are moniliform (Figure 2B). Branchiae are pectinate with about 8 filaments in the middle setigers (Figure 2C). Pygidium presents with a pair of articulated anal cirri. Subacicular hooks are light yellow, tridentate with teeth in a crest (Figure 2D).

Habitat. Coral sand bottom (Hoagland 1920); artificial hardbottom

Distribution. Tinakta Island, Caguayan Point, off Leyte Island, Philippines (Hoagland 1920); Tanjung Priok Port of Jakarta, Indonesia (this study).

\subsubsection{Family Nereididae Blainville, 1818}

Ceratonereis mirabilis Kinberg, 1865 (Figure 3A-E)

Ceratonereis mirabilis in Day 1967: 324; fig. 14.10a-g. 


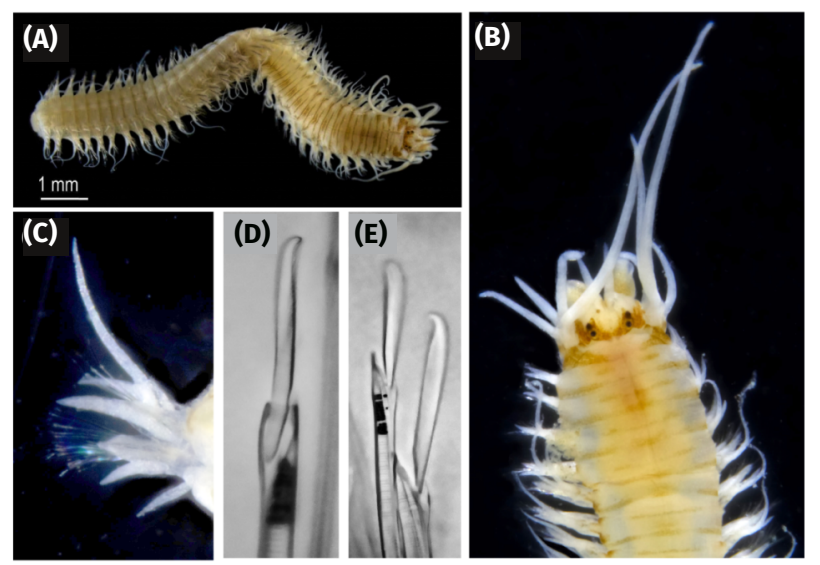

Figure 3. Ceratonereis mirabilis Kinberg, 1865. (A) incomplete animal with posterior end missing; (B) anterior end; (C) parapodia; (D) notosetae; (E) neurosetae.

Material examined. 1 specimen (POL 76), Tanjung Priok Port, Jakarta, 19th November 2011, Hadiyanto; 1 specimen (POL 77), Tanjung Priok Port, Jakarta, 18th December 2011, Hadiyanto; 3 specimens (POL 78), Tanjung Priok Port, Jakarta, 17th January 2012, Hadiyanto.

Diagnosis. The length of entire body is around 10-12 mm (Figure 3A). Prostomium is cleft (Figure 3B). Eversible pharynx presents with paragnaths on the maxillary ring only. Anterior parapodia present with long dorsal cirri, and two notopodial lobes (Figure 3C). Notosetae are homogomph falcigers with long blades in posterior feet (Figure 3D). Neurosetae are heterogomph falcigers and long blades with hooked tips (Figure 3e).

Habitat. Estuarine, intertidal, subtidal (Day 1967); more frequently from rocky shores than from sandy beaches (Fauchald 1973); soft bottoms in the continental shelf, in sediments accumulated among roots of algae attached to coral rocks (de Leon-Gonzalez et al. 1999); artificial hardbottom.

Distribution. Brazil, Gulf of Mexico, Red Sea, Indo-west Pacific (Day, 1967); in warm waters and may be circumtropical (Fauchald 1973); the Pacific Ocean, the Indian Ocean and the Atlantic Ocean (Wu et al. 1985); tropical Western Atlantic, known from the Gulf of Mexico and Caribbean Sea (de Leon-Gonzalez et al. 1999); Japan (Imajima 2003); Tanjung Priok Port of Jakarta, Indonesia (this study).

\section{Leonnates decipiens Fauvel, 1929 (Figure 4A-D)}

Leonnates decipiens var. manilensis Pillai 1965: 144-148; fig. 13-14

Leonnates decipiens in Day 1967: 330; fig. 14.11n-s.
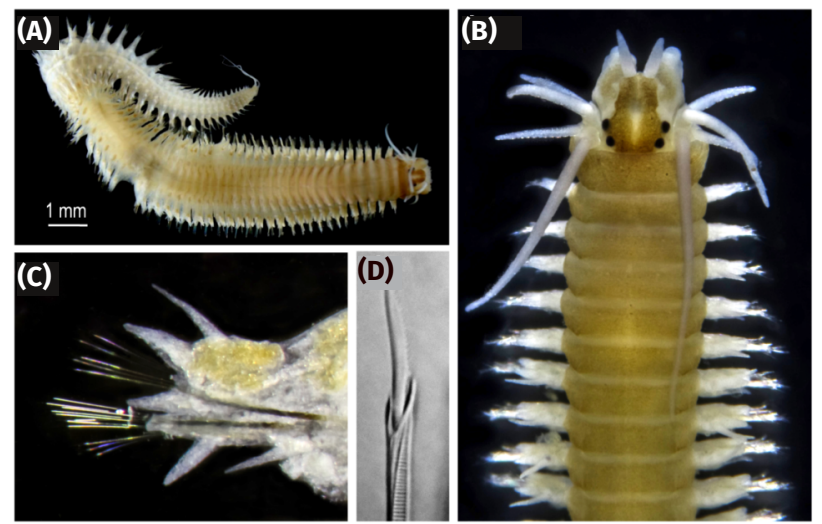

Figure 4. Leonnates decipiens Fauvel, 1929. (A) entire worm; (B) anterio end; (C) parapodia; (D) neurosetae.

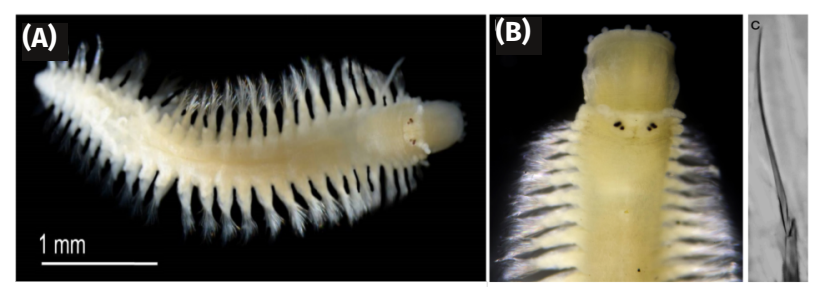

Figure 5. Namanereis sp. (A) entire worm; (B) anterior end; (C) neurosetae.

Material examined. 2 specimens (POL 79), Tanjung Priok Port, Jakarta, $17^{\text {th }}$ January 2012, Hadiyanto

Diagnosis. The length of entire worm is about $22 \mathrm{~mm}$ (Figure 4A). Prostomium is not notched (Figure 4B). Eversible pharynx presents with papillae on the oral ring and paragnaths on the maxillary ring. In the middle feet, the dorsal ligule is shorter than the dorsal cirri, while the ventral ligule is longer than the ventral cirri (Figure 4C). Notosetae are homogomph spinigers. Neurosetae are homogomph spinigers and falcigers. Falcigers present with stout, abruptly truncate ends to the blades (Figure 4D).

Habitat. Oyster farm (Pillai 1965); intertidal (Day 1967); artificial hardbottom.

Distribution. Congo, Senegal, Mozambique, Northern Territory of Australia, Gulf of Mannar, Suez Canal, Sri Lanka (Day 1967), Guangdong and Guangxi Provinces of China (Qiu and Qian 2000); Tanjung Priok Port of Jakarta, Indonesia (this study).

\section{Namanereis sp. (Figure 5A-C)}

Material examined. 3 specimens (POL 80), Tanjung Priok Port, Jakarta, $18^{\text {th }}$ December 2011, Hadiyanto; 3 specimens (POL 81), Tanjung Priok Port, Jakarta, 17th January 2012, Hadiyanto

Remarks. The length of specimens was $<4 \mathrm{~mm}$ with the number of segments was around 27-30 (Figure 5A). Prostomium presents with two pairs of eyes; anterior eye is bigger. Tentacular cirri cannot be observed. Papillae present on oral ring only, single row of 10 papillae on Areas VII-VIII (Figure 5B). Parapodia are uniramous; neurosetae are heterogomph spinigers (Figure 5C).

\subsubsection{Family Opheliidae Malmgren, 1867}

Polyophthalmus pictus (Dujardin, 1839) (Figure 6A-C) Polyophthalmus pictus in Day 1967: 579-580; fig. 25.2k-m.

Material examined. 3 specimens (POL 82), Tanjung Priok

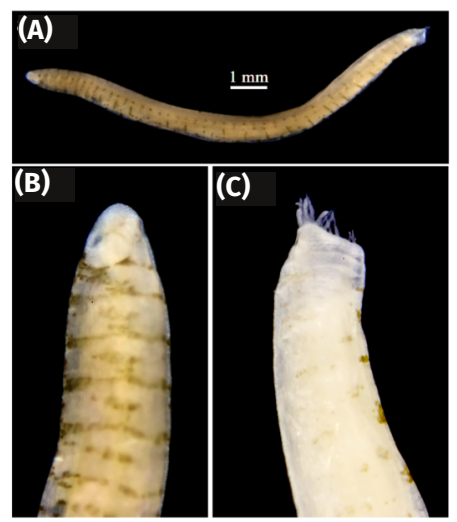

Figure 6. Polyophthalmus pictus (Dujardin, 1839). (A) entire worm; (B) anterior end; (C) posterior end. 

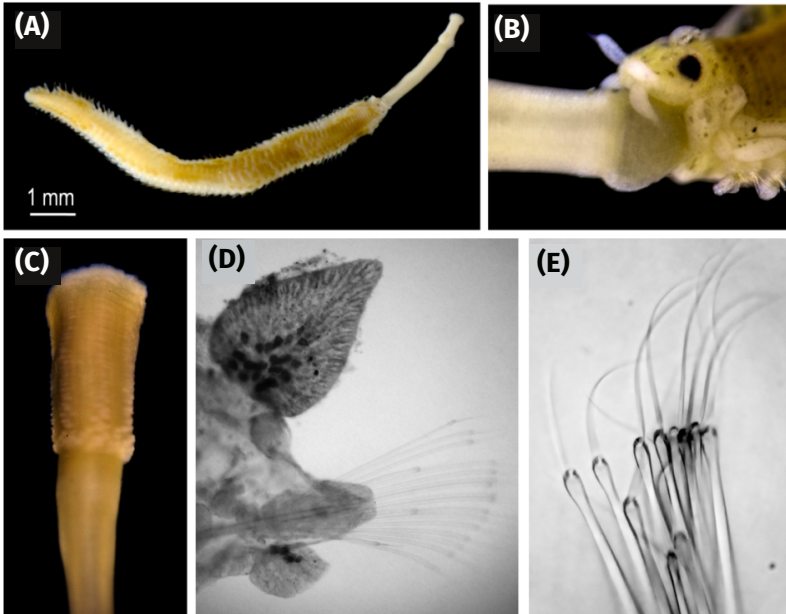

(E)

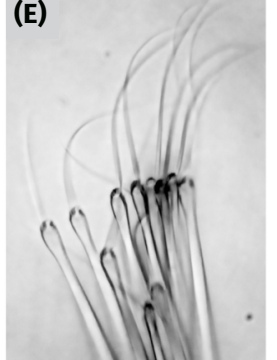

Figure 7. Eulalia (Eumida) sanguinea Örsted, 1843. (A) entire worm; (B) prostomium with 5 antennae; (C) proboscis; (D) parapodia; (E) neurosetae.

Port, Jakarta, $19^{\text {th }}$ November 2011, Hadiyanto; 4 specimens (POL 83), Tanjung Priok Port, Jakarta, $18^{\text {th }}$ December 2011, Hadiyanto.

Diagnosis. The length of entire body is about $14 \mathrm{~mm}$ (Figure $6 \mathrm{~A})$. Ventrum is deeply grooved along the whole length. Prostomium is rounded (Figure 6B). Branchiae are absent; lateral eyes are present. Anal tube is short with small anal cirri (Figure 6C).

Habitat. Intertidal and estuarine, cryptic on Halichondria sp. and seaweed, seagrass, muddy sand; subtidal on artificial hardbottom.

Distribution. All warm tropical seas, Atlantic from the English Channel to the Gulf of Mexico and tropical west Africa, Madagascar, Mediterranean, Red Sea, Indo Pacific to Japan (Day 1967), western Canada and Southern California, Solomon Island, New Zealand (Gibbs 1971), Tanjung Priok Port of Jakarta.

\subsubsection{Family Phyllodocidae Örsted, 1843}

Eulalia (Eumida) sanguinea Örsted, 1843 (Figure 7A-E) Eulalia (Eumida) sanguinea in Day 1967: 155; fig. 5.5a-c. Eumida sanguinea in Pettibone 1963: 88-90; fig. 21a-b.

Material examined. 1 specimen (POL 84), Tanjung Priok Port, Jakarta, $19^{\text {th }}$ November 2011, Hadiyanto; 1 specimen (POL 85), Tanjung Priok Port, Jakarta, $18^{\text {th }}$ December 2011, Hadiyanto; 1 specimen (POL 86), Tanjung Priok Port, Jakarta, $17^{\text {th }}$ January 2012, Hadiyanto.

Diagnosis. The length of entire body without proboscis is about $11 \mathrm{~mm}$ (Figure 7A). Prostomium is cordiform with two large eyes. There are five antennae; four antennae anteriorly and a fifth inserted in front of the eyes (Figure 7B). The first tentacular segment is fused to the prostomium, while the second and third are free from one another. Tentacular cirri are somewhat flattened. Proboscis presents with unclear papillae (Figure 7C). Dorsal cirri are cordate, while ventral cirri are ovoid, and shorter than setigerous lobe (Figure 7D). Setae have oval striatedheads and tapered blades (Figure 7E).

Remarks. These specimens are close to Eumida sanguinea Pettibone 1963, but their tentacular cirri and ventral cirri are different. Tentacular cirri of these specimens are flattened, while tentacular cirri of Eumida sanguinea Pettibone 1963 are cylindrical. Ventral cirri of these specimens are shorter than setigerous lobes, while ventral cirri of Eumida sanguinea Pettibone 1963 are about length of setigerous lobes.
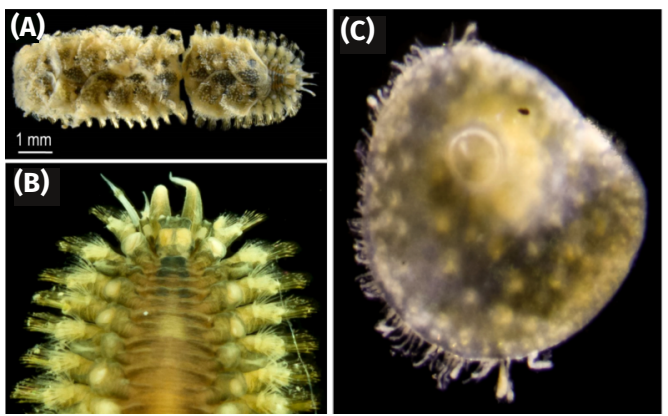

(D)

Figure 8. Lepidonotus tenuisetosus (Gravier, 1902). (A) entire worm; (B) anterior end after elytra clearance; (C) elytra; (d) neurosetae.

Habitat. Intertidal to $600 \mathrm{~m}$ (Day, 1967; 1973), artificial hard bottom.

Distribution. Cosmopolitan in temperate and tropical seas (Day, 1967; 1973).

\subsubsection{Family Polynoidae Malmgren, 1867}

Lepidonotus tenuisetosus (Gravier, 1902) (Figure 8A-D) Lepidonotus tenuisetosus in Misra 1998: 133-134.

Material examined. 2 specimens (POL 89), Tanjung Priok Port, Jakarta, $17^{\text {th }}$ January 2012, Hadiyanto.

Diagnosis. The length of body is about $10 \mathrm{~mm}$ (Figure 8A). Overall, there are twelve pairs of elytra. Prostomium is relatively longer than broader (Figure 8B). Elytra presents with fringed margins; and tubercles on the elytra are small and rounded to conical (Figure $8 \mathrm{C}$ ). Notosetae are slender and serrated, while neurosetae are rows of coarse teeth and unidentate (Figure 8D).

Habitat. Intertidal (Day 1967); crevices of wooden posts and pillars of jetty towards low water mark, salinity 8-19 ppt (Misra 1998); artificial hardbottom.

Distribution. Tropical West Africa, Red Sea, Indo-west Pacific to Japan (Day 1967); West Bengal (Misra 1998); Tanjung Priok Port of Jakarta, Indonesia.

\subsubsection{Family Sabellidae Latreille, 1825}

Hypsicomus sp. 1 (Figure 9A-D)

Material examined. 1 specimen (POL 90), Tanjung Priok Port, Jakarta, $19^{\text {th }}$ November 2011, Hadiyanto; 3 specimens
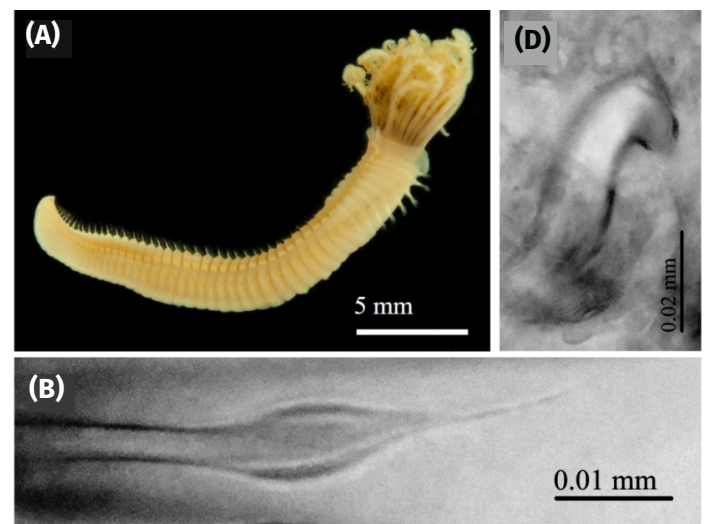

(c)

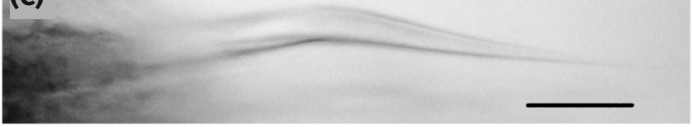

Figure 9. Hypsicomus sp. 1. (A) entire worm; (B) palea; (C) abdominal neurosetae; (D) avicular uncini. 


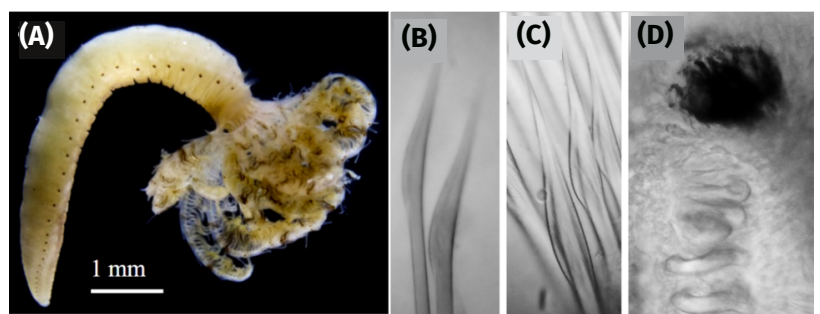

Figure 10. Hypsicomus sp. 2: (A) entire worm, (B) winged capillary setae, (C) palea, (D) avicular uncini.

(POL 91), Tanjung Priok Port, Jakarta, $18^{\text {th }}$ December 2011, Hadiyanto; 4 specimens (POL 92), Tanjung Priok Port, Jakarta, 17th January 2012, Hadiyanto.

Remarks. The length of entire body without radioles is about $20 \mathrm{~mm}$ (Figure 9A). Eyes are scattered over the radioli. Collar is very low with a smooth, straight, continuous margin. Thoracic notosetae are (a) winged capillaries with normal tapered blades, (b) palea with broad blade and a long tip (Figure 9B). Thoracic neurosetae presents a row of avicular uncini (Figure 9C). Abdominal notosetae are similar to the avicular uncini of the thorax. Abdominal neurosetae are very slender winged capillaries with long narrow blades (Figure 9D).

\section{Hypsicomus sp. 2 (Figure 10A-D)}

Material examined. 1 specimen (POL 93), Tanjung Priok Port, Jakarta, $19^{\text {th }}$ November 2011, Hadiyanto; 4 specimens (POL 94), Tanjung Priok Port, Jakarta, $18^{\text {th }}$ December 2011, Hadiyanto; 2 specimens (POL 95), Tanjung Priok Port, Jakarta, $17^{\text {th }}$ January 2012, Hadiyanto

Remarks. The length of entire body without branchial crown is about $7 \mathrm{~mm}$. Four to ten pairs of eyes present along radioli. Interramal eyes present from thoracic segments to abdominal segments (Figure 10A). Thoracic notosetae (i.e. winged capillary setae and palea) and neurosetae (i.e. avicular uncini) are similar to those of Hypsicomus sp. 1 (Figure 10B-D).

\subsubsection{Family Serpulidae Rafinesque, 1815}

Hydroides elegans Haswell, 1883 (Figure 11A-E)

Hydroides elegans in Bastida-Zavala and Ten Hove 2002: 164-167; fig. 35A-J, 36.

Material examined. 4 specimens (POL 96), Tanjung Priok Port, Jakarta, $19^{\text {th }}$ November 2011, Hadiyanto; 3 specimens (POL 97), Tanjung Priok Port, Jakarta, $18^{\text {th }}$ December 2011, Hadiyanto.

Diagnosis. The length of entire body without branchial

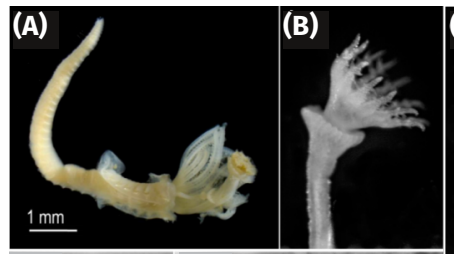

(D)

(E)

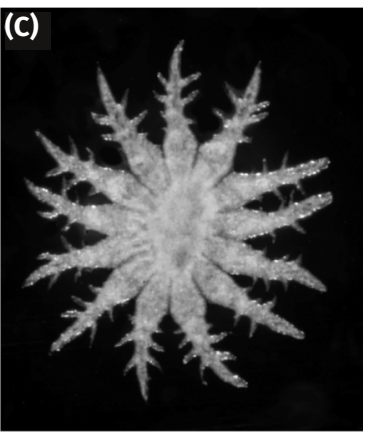

Figure 11. Hydroides elegans (Haswell, 1883). (A) entire worm; (B) lateral view of operculum; (C) apical view of operculum; (D) bayonet setae; (E) thoracic uncini. crown is about $6 \mathrm{~mm}$ (Figure 11A). Branchial crown consists of 10 radioles with long terminal filament. Funnel presents with blunt tip radii (Figure 11B). Verticil consists of 13 similar spines in shape and size, with pointed tip. Each spine has 3 pairs of lateral spinules (Figure 11C). Collar setae are bayonet setae with two pointed-elongate teeth and a proximal rasp, distal blades are present with many denticles and a conspicuous notch (Figure 11D); and capillary setae are present with denticles distally. Thoracic membranes are well developed, that consist of six setigers with limbate setae and saw-shaped uncini (Figure 11E).

Habitat. Depth: 0.4-7 m, on rocky and wooden piers and ships' bottoms, in lagoons, fouling, salinity tolerance ranges 30-37 ppt (Bastida-Zavala and Ten Hove 2002).

Distribution. Circum (sub)tropical (Bastida-Zavala and Ten Hove 2002).

\subsubsection{Family Spionidae Grube, 1850}

Polydora ciliata (Johnston, 1838) (Figure 12A-D) Polydora ciliata in Day 1967: 469-471; fig. 18.3.i-j.

Material examined. 2 specimens (POL 98), Tanjung Priok Port, Jakarta, $19^{\text {th }}$ November 2011, Hadiyanto, 1 specimen (POL 99), Tanjung Priok Port, Jakarta, $18^{\text {th }}$ December 2011, Hadiyanto.

Diagnosis. The length of entire body is about $5 \mathrm{~mm}$ (Figure 12A). Prostomium was anteriorly bifid. Caruncle prolongs to setiger 3. Dorsal superior and ventral inferior fascicle are present on setiger 5 . Branchiae are present from setiger 7 (Figure 12B). Setiger 5 is strongly modified with stout setae. Major spines of setiger 5 present with a very small accessory tooth (Figure 12C). Hooded and bidentate hooks present from setiger 7 (Figure 12D).

Remarks. The length of accessory tooth of these specimens is much shorter than those described by Day (1967). Habitat. Estuary, intertidal zone, and shallow water (1-99 m) (Day 1967)

Distribution. Baltic Sea; North Atlantic, Falkland Island, Mediterranean, Red Sea, India, Madagascar, N. W. Japan (Day 1967), and Tanjung Priok Port of Jakarta, Indonesia (this study).

\section{DISCUSSION}

According to previous reports from Horst (1912; 1917; 1924), Mesnil and Fauvel (1939), Caullery (1944), Pillai (1965), AlHakim and Glasby (2004) and Aguado et al. (2008), there are 525 species of polychaetes in Indonesia, although this

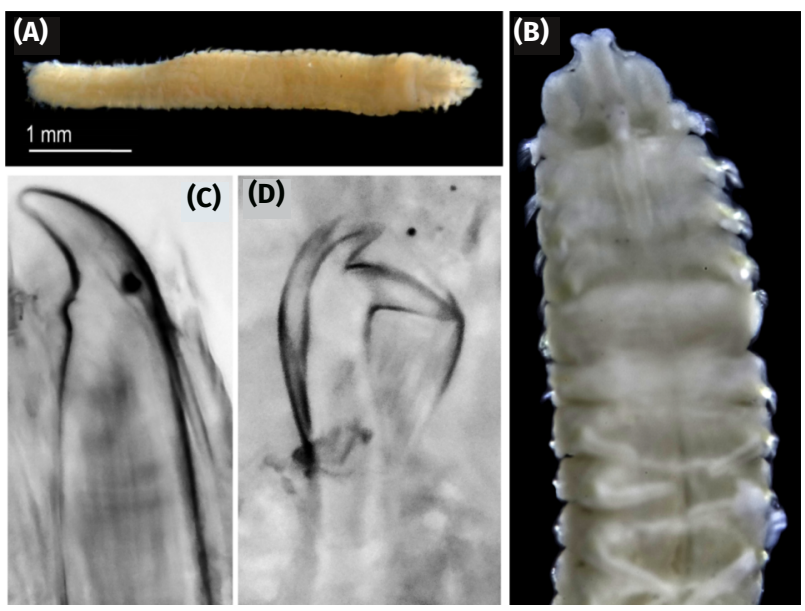

Figure 12. Polydora ciliata (Johnston, 1838). (A) entire worm; (B) anterior end; (C) major spine; (D) hook. 
number is not verified. This study augments previous reports about biodiversity of Polychaeta in Indonesian waters. Some specimens are complete and deposited in good condition, so in the future these can be described for a more detailed taxonomic report. Nine species are indicated as new records in Indonesian waters because they are not recorded in the previous studies. Actually, finding a new record of polychaete species in Indonesian waters is not surprising, particularly fouling species, because previous studies only collected specimens from offshore (Horst 1912, Horst 1917, Horst 1924; Mesnil and Fauvel 1939; Caullery 1944; Al-Hakim and Glasby 2004; Aguado et al. 2008) and milkfish farms (Pillai 1965).

Compared with other tropical regions, species richness of fouling polychaetes in Tanjung Priok Port was high. For instance, in Eastern harbour of Alexandria, Egypt (Ramadan et al. 2006), and in Pondicherry, India (Babu et al. 2011), only one polychaete species was recorded in fouling communities. On floating installations west of Dongsha Islands, the northern South China Sea, three species were reported upon (Yan et al. 2009), although on a petroleum platform in the northern Gulf of Mexico, there were nine species (Lewbel et al. 1987). The difference in species richness between locations is determined by global drivers, e.g., temperature (Tittensor et al. 2010; Belanger et al. 2012) as well as local drivers, e.g. substratum type (van Dolah et al. 1988; Anderson and Underwood 1994; James and Underwood 1994; Todd and Keough 1994), anthropogenic activities (Morant 1991, Morant and Grant 1991; Morant and Grant 1993; Mayer-Pinto and Junqueira 2003), and seasons (van Dolah et al. 1988; Swami and Udhayakumar 2010).

The species composition of fouling polychaetes in Tanjung Priok of Jakarta also differed from that in other tropical regions (Lewbel et al. 1987; Ramadan et al. 2006; Yan et al. 2009; Babu et al. 2011). A visual inspection showed that the individual number of tube-worms (Serpulidae and Sabellidae) was higher than that of other species. A small serpulid Hydroides elegans is common in fouling communities (Relini et al. 1998a; Babu et al. 2011) allowing this species to be an excellent model for biofouling research (Nedved and Hadfield 2008).

As indicated in the species list, most of the fouling polychaetes in Tanjung Priok Port of Jakarta are native species. Although they have never been found previously in Indonesian waters, they are recorded from the tropical region of the Indian Ocean that close to Indonesian waters for a long time. Ceratonereis mirabilis, Leonnates decipiens, Polyophthalmus pictus, Lepidonotus tenuisetosus, Eulalia (Eumida) sanguinea, Hydroides elegans, and Eunice hirschi are typical Indo-West Pacific species (Hoagland 1920; Day 1967; Tan and Chou 1993).

An interesting observation is that the native polychaetes in Indonesia are alien species in other countries. For instance, Ceratonereis mirabilis and Leonnates decipiens are alien species in the Mediterranean Sea due to Lessepsian migration (Zenetos et al. 2005; Cinar and Dagli 2012); Hydroides elegans is an alien species in the Hawaiian Islands, as well as Mediterranean countries. The species also occur in the Azores, Portugal, and the British Isles, introduced by hull fouling (Coles et al. 1999; Zenetos et al. 2005; Cardigoz et al. 2006; Minchin et al. 2013). In the Mediterranean Sea, Hydroides elegans was one of the "100 worst invasive species" impacting the biodiversity, infrastructure, and building (Steftaris and Zenetos 2006).

As the polychaetes collected in this study were native species, the list of marine alien species in Indonesia does not change which still consists of nine species (Calcinai et al. 2004; Kawaroe and Sunuddin 2010). Other countries have listed extensively their marine alien species, including Mediterranean countries (Zenetos et al. 2005), South Africa (Griffiths et al. 2009), Chile (Castilla et al. 2005), Turkey (Cinar and Dagli 2012), and United Kingdom (Minchin et al. 2013). List of alien species is a baseline study to monitor continually and prevent the introduction of species. Preventing the introduction of harmful alien species is normally considered the first and the most costeffective approach to manage this species (Davis 2009).

While non-indigenous polychaetes are not recorded yet in Indonesia, they already occur in other countries, such as Chile (two species; Castilla et al. 2005), Turkey (two species; Cinar and Dagli 2012), Hawaiian Islands (four species; Coles et al. 1999), Western Australia (four species; Wells et al. 2009), Italy (five species; Gravilli et al. 2010), British Isles (ten species; Minchin et al. 2013), and Mediterranean countries (54 species; Zenetos et al. 2005). As monitoring of marine alien species, especially Polychaeta, in Indonesian waters is a relatively new activity, it is not surprising that alien polychaetes have not been detected in Indonesia to date. In addition, the specimens from this study are only collected from fouling communities, while those of previous studies are collected from various habitats, i.e., not only from fouling communities but also from natural soft or hard bottom habitats.

The status of Namanereis sp., Hypsicomus sp. 1, and Hypsicomus sp. 2 in Indonesian waters remains unclear. Although they are morphologically distinct species, their binomial name could not be determined. The specimens of Namanereis sp. were very small and not in a good condition, while some taxonomic characters of Hypsicomus spp. could not be elucidated.

The determination of alien species in the present study or other previous studies are mainly based on the geographical distribution from taxonomic reports (Bonaca 2001; Castilla et al. 2005; Zenetos et al. 2005; Ranasinghe et al. 2005; Cardigos et al. 2006; Griffiths et al. 2009; Wells et al. 2009; Gravilli et al. 2010; Buschbaum et al. 2012; Cinar and Dagli 2012; Minchin et al. 2013), because species generally have discrete distributions (Hutchings 1998). However, ecological surveys based on the observational methods are unable to identify clearly cryptogenic taxa, source populations, multiple introductions, or genetic diversity. Molecular genetic techniques are needed to identify the most likely source populations (Holland 2000).

\section{CONCLUSIONS}

Fouling polychaetes in Tanjung Priok Port of Jakarta consisted of twelve species belonging to nine families; nine species were likely to be native species and three species were undetermined.

\section{ACKNOWLEDGEMENTS}

This paper is part of ASEAN-India Cooperation Project 2010-2014 "Extent of transfer of alien organisms in South/SE Asia region by shipping" coordinated by Dr. Tan Koh Siang (Tropical Marine Science Institute, National University of Singapore, Singapore) and Dr. A. C. Anil (National Institute of Oceanography, India).

\section{REFERENCES}

Aguado MT, San Martin G, ten Hove HA. 2008. Syllidae (Annelida: Polychaeta) from Indonesia collected by 
the Siboga (1899-1900) and Snellius II (1984) expeditions. Zootaxa 1673:1-48.

Al-Hakim I, Glasby CJ. 2004. Polychaeta (Annelida) of the Natuna Islands, South China Sea. The Raffles Bulletin of Zoology, Supplement 11:25-45.

Almeida E, Diamantino TC, De Sousa O. 2007. Marine paints: the particular case of antifouling paints. Progress in Organic Coatings 59:2-20.

Anderson MJ, Underwood AJ. 1994. Effects of substratum on the recruitment and development of an intertidal estuarine fouling assemblage. Journal of Experimental Marine Biology and Ecology 184:217-236.

Arias A, Giangrande A, Gambi MC, Anadon N. 2013. Biology and new records of the invasive species Branchiomma bairdi (Annelida: Sabellidae) in the Mediterranean Sea. Mediterranean Marine Science 14(1):162-171.

Babu RA, Yogamoorthi A, Sankar RS, Kaviarasan T. 2011. Distribution of macro fouling community in the coastal region of Pondicherry, India. International Journal of Fisheries and Aquatic Sciences 1(2):147-149.

Bastida R, Capezzani A, Torti MR. 1971. Fouling organisms in the port of Mar del Plata (Argentina). I. Siphonaria lessoni: ecological and biometric aspects. Marine Biology 10(4):297-307.

Bastida-Zavala JR, ten Hove HA. 2002. Revision of Hydroides Gunnerus, 1768 (Polychaeta: Serpulidae) from the Western Atlantic Region. Beaufortia 52(9):103-179.

Bax N, Williamson A, Aguero M, Gonzalez E, Geeves W. 2003. Marine invasive alien species: a threat to global biodiversity. Marine Policy 27:313-323.

Belanger CL, Jablonski D, Roy K, Berke SK, Krug AZ, Valentine JW. 2012. Global environmental predictors of benthic marine biogeographic structure. Proceedings of the National Academy of Sciences of the United States of America 109:14046-14051.

Bonaca MO. 2001. A survey of the introduced non-indigenous species in the northern Adriatic Sea. Annals for Istrian and Mediterranean Studies, Series Historia Naturalis 2(25):149-158.

Buschbaum C, Lackschewitz D, Reise K. 2012. Nonnative macrobenthos in the Wadden Sea ecosystem. Ocean \& Coastal Management 68:89-101.

Calcinai B, Bavestrello G, Cerrano C. 2004. Dispersal and association of two alien species in the Indonesian coral reefs: the octocoral Carijoa riisei and the demosponge Desmapsamma anchorata. Journal of the Marine Biological Association of the UK 84(05):937-941.

Cardigoz F, Tempera F, Avila S, Goncalves J, Colaco A, Santos RS. 2006. Non-indigenous marine species of the Azores. Helgoland Marine Research 60:160-169.

Castilla JC, Uribe M, Bahamonde N, Clarke M, DesqueyrouxFaundez R, Kong I, Moyano H, Rozbaczylo N, Santelices B, Valdovinos C, Zavala P. 2005. Down under the southeastern Pacific: marine nonindigenous species in Chile. Biological Invasions 7:213-232.

Caullery M. 1944. Polychètes sédentaires de l'expédition du Siboga: Ariciidae, Spionidae, Chaetopteridae, Chlohaemidae, Opheliidae, Oweniidae, Sabellariidae, Sternaspidae, Amphictenidae, Ampharetidae and Terebellidae. Leiden: EJ Brill.

Cinar ME, Dagli E. 2012. New records of alien polychaete species for the coasts of Turkey. Mediterranean Marine Science 13(1):103-107.

Coles SL, DeFelice RC, Eldredge LG, Carlton JT. 1999.
Historical and recent introductions of nonindigenous marine species into Pearl Harbor, Oahu, Hawaiian Islands. Marine Biology 135:147-158.

David M, Gollasch S, Cabrini M, Perkovic M, Bosnjak D, Virgilio D. 2007. Results from the first ballast water sampling study in the Mediterranean Sea - the Port of Koper study. Marine Pollution Bulletin 54:53-65.

Davis MA. 2009. Invasion biology. Oxford: Oxford University Press.

Day JH. 1967. A monograph on the polychaeta of southern Africa. Part I. Errantia. London: The British Museum (Natural History).

Day JH. 1973. New Polychaeta from Beaufort, with a key to all species recorded from North Carolina. NOAA Technical Report, NMFS Circular 375:1-140.

de Leon-Gonzalez JA, Solis-Weiss V, Rivera VO. 1999. Nereidids (Polychaeta) from the Caribbean Sea and adjacent Coral Islands of the southern Gulf of Mexico. Proceedings of the Biological Society of Washington 112(4):667-681.

Drake JM, Lodge DM. 2007. Hull fouling is a risk factor for intercontinental species exchange in aquatic ecosystems. Aquatic Invasions 2(2):121-131.

El Haddad M, Azzati RC, Garcia-Carrascosa AM. 2007. Branchiomma luctuosum (Polychaeta: Sabellidae): a non-indigenous species at Valencia Port (western Mediterranean Sea, Spain). Marine Biodiversity Records 1:1-7.

Fauchald K. 1973. Polychaetes from Central American sandy beaches. Bulletin of the Southern California Academy of Sciences 72:19-31.

Fauchald K. 1992. A review of the genus Eunice (Eunicidae: Polychaeta) based upon type material. Smithsonian Contribution to Zoology 523:1-422.

Gibbs PE. 1971. The polychaete fauna of the Solomon Islands. Bulletin of the British Museum (Natural History) Zoology 21(5):99-211.

Gravilli C, Belmonte G, Cecere E, Denitto F, Giangrande A, Guidetti P, Longo C, Mastrototaro F, Moscatello S, Petrocelli A, Piraino S, Terlizzi A, Boero F. 2010. Nonindigenous species along the Apulian coast, Italy. Chemistry and Ecology 26:121-142.

Griffiths CL, Robinson TB, Mead A. 2009. The status and distribution of marine alien species in South Africa. In: Rilov G, Crooks JA, editors. Biological invasions in marine ecosystems. Berlin, Heidelberg: SpringerVerlag. p. 393-408.

Hamer JP, Walker G, Latchford JW. 2001. Settlement of Pomatoceros lamarckii (Serpulidae) larvae on biofilmed surfaces and the effect of aerial drying. Journal of Experimental Marine Biology and Ecology 260:113-131.

Hoagland RA. 1920. Polychaetous annelids collected by the United States fisheries steamer "Albatross" during the Philippine expedition of 1907-1909. Bulletin of the United States National Museum 100(1)(9):603-635.

Holland BS. 2000. Genetics of marine bioinvasions. Hydrobiologia 420:63-71.

Horst R. 1912. Polychaeta errantia of the Siboga Expedition. Part I. Amphinomidae. Leiden: EJ Brill.

Horst R. 1917. Polychaeta errantia of the Siboga Expedition. Part II. Aproditidae and Chrysopetalidae. Leiden: EJ Brill.

Horst R. 1924. Polychaeta errantia of the Siboga Expedition. Part III. Nereididae and Hesionidae. Leiden: EJ Brill.

Hutchings P. 1998. Biodiversity and functioning of 
polychaetes in benthic sediments. Biodiversity and Conservation 7:1133-1145.

Hutchings P, Glasby C. 2004. Port surveys for introduced marine species - and the fate of the material collected. Marine Pollution Bulletin 48:1009-1011.

Imajima M. 2003. Polychaetous annelids from Sagami Bay and Sagami Sea collected by the Emperor Showa of Japan and deposited at the Showa Memorial Institute, National Science Museum, Tokyo (II). National Science Museum Monographs 23:1-221.

James RJ, Underwood AJ. 1994. Influence of colour of substratum on recruitment of spirorbid tubeworms to different types of intertidal boulders. Journal of Experimental Marine Biology and Ecology 181:105-115.

Kawaroe M, Sunuddin A. 2010. Indonesia. In: Chavanich S, Tan LT, Vallejo B, Viyakarn V, editors. Report on the current status of marine non-indigenous species in the Western Pacific region. Bangkok: Intergovernmental Oceanographic Commission, Sub-Commission for the Western Pacific (IOC/WESPAC). p. 18-20.

Lewbel GS, Howard RL, Gallaway BJ. 1987. Zonation of dominant fouling organisms on northern Gulf of Mexico petroleum platforms. Marine Environmental Research 21:199-224.

Mayer-Pinto M, Junqueira AOR. 2003. Effects of organic pollution on the initial development of fouling communities in a tropical bay, Brazil. Marine Pollution Bulletin 46:1495-1503.

Mesnil F, Fauvel P. 1939. Polychètes sédentaires de l'expédition du Siboga: Maldanidae, Cirratulidae, Capitellidae, Sabellidae et Serpulidae. Leiden: EJ Brill.

Minchin D, Cook EJ, Clark PF. 2013. Alien species in British brackish and marine waters. Aquatic Invasions 8(1):3-19.

Misra A. 1998. Zoological survey of India. Polychaetes. State Fauna Series 3: Fauna of West Bengal 10:125-225.

Morant PJ. 1991. The effects of dredging on the larval settlement and community development of fouling organisms in Port Kembla Harbour, Australia. Water Research 25(9):1151-1155.

Morant PJ, Grant TR. 1991. Transference of marine fouling communities between polluted and unpolluted sites: impact on structure. Environmental Pollution 72:89-102.

Morant PJ, Grant TR. 1993. Larval settlement of marine fouling organisms in polluted water from Port Kembla Harbour, Australia. Marine Pollution Bulletin 26(9):512-514.

Muniz P, Clemente J, Brugnoli E. 2005. Benthic invasive pests in Uruguay: a new problem or an old one recently perceived? Marine Pollution Bulletin 50:993-1018.

Nedved BT, Hadfield MG. 2008. Hydroides elegans (Annelida: Polychaeta): a model for biofouling research. Springer Series on Biofilms 4:203-217.

Pettibone MH. 1963. Marine polychaete worms of the New England region. I. Aphroditidae through Trochochaetidae. Bulletin of the United States National Museum 227:1-356.

Pillai TG. 1965. Annelida Polychaeta from the Philippines and Indonesia. Ceylon Journal of Science (Biological Sciences) 5(2):112-177.

PT. Pelabuhan Indonesia II. 2012. Arus Kunjungan Kapal per Unit. [accessed 2013 Sep 26]. http://www.priokport.co.id/index.php? $\bmod =$ statistik\&smod=arus_kp11.
Qiu J. Qian P. 2000. Revision of the genus Leonnates Kinberg, 1866 (Polychaeta: Nereididae), with descriptions and comments on other species described in Leonnates. Proceedings of the Biological Society of Washington 113(4):1111-1146.

Railkin AI. 2004. Biofouling: colonisation processes and defenses. New York: CRC Press.

Ramadan SE, Kheirallah AM, Abdel-Salam KM. 2006. Marine fouling community in the Eastern harbour of Alexandria, Egypt compared with four decades of previous studies. Mediterranean Marine Science 7(2):19-29.

Ranasinghe JA, Mikel TK, Velarde RG, Weisberg SB, Montagne DE, Cadien DB, Dalkey A. 2005. The prevalence of non-indigenous species in southern California embayments and their effects on benthic macroinvertebrate communities. Biological Invasions 7:679-686.

Relini G, Tixi F, Relini M, Torchia G. 1998a. The macrofouling on offshore platforms at Ravenna. International Biodeterioration \& Biodegradation 41:41-55.

Relini G, Tixi F, Relini M, Torchia G. 1998b. Settlement on concrete blocks immersed in the Lingurian Sea $(\mathrm{N}-$ W Mediterranean). International Biodeterioration \& Biodegradation 41:57-65.

Ricciardi A, Rasmussen JB. 1998. Predicting the identity and impact of future biological invaders: a priority for aquatic resource management. Canadian Journal of Fisheries \& Aquatic Sciences 55(7):1759-1765.

Ruiz GM, Carlton JT, Grosholtz ED, Hines AH. 1997. Global invasions of marine and estuarine habitats by nonindigenous species: mechanisms, extent and consequences. American Zoologist 37:621-632.

Stachowitsch M, Kikinger R, Herler J, Zolda P, Geutebruck E. 2002. Offshore oil platforms and fouling communities in the southern Arabian Gulf (Abu Dhabi). Marine Pollution Bulletin 44:853-860.

Streftaris N, Zenetos A. 2006. Alien marine species in the Mediterranean - the 100 "Worst Invasives" and their impact. Mediterranean Marine Science 7(1):87-118.

Swami BS, Udhayakumar M. 2010. Seasonal influence on settlement, distribution and diversity of fouling organisms at Mumbai harbor. Indian Journal of Marine Sciences 39(1):57-67.

Tan LT, Chou LM. 1993. Checklist of polychaete species from Singapore waters (Annelida). Raffles Bulletin of Zoology 41(2):279-295.

Tittensor DP, Mora C, Jetz W, Lotze HK, Richard D, Berghe EV, Worm B. 2010. Global patterns and predictors of marine biodiversity across taxa. Nature 466:1098-1101.

Todd CD, Keough MJ. 1994. Larval settlement in hard substratum epifaunal assemblages: a manipulative field study of the effects of substratum filming and the presence of incumbents. Journal of Experimental Marine Biology and Ecology 181:159-187.

Toonen RJ, Pawlik JR. 1996. Settlement of the tube worm Hydroides dianthus (Polychaeta: Serpulidae): cues for gregarious settlement. Marine Biology 126:725-733.

van Dolah RF, Wendt PH, Knott DM, Wenner EL. 1988. Development of sessile fouling assemblages on the Continental Shelf off South Carolina, USA. Estuarine, Coastal and Shelf Science 26:679-699.

Wells FE, McDonald JI, Huisman JM. 2009. Introduced marine species in Western Australia. Perth: Fisheries Occasional Publications. 
Wilhelmsson D, Malm T. 2008. Fouling assemblages on offshore wind power plants and adjacent substrata. Estuarine, Coastal and Shelf Science 79:459-466.

Williams RJ, Griffiths FB, Van der Wal EJ, Kelly J. 1988. Cargo vessel ballast water as a vector for the transport of non-indigenous marine species. Estuarine, Coastal and Shelf Science 26:409-420.

Wu B, Sun R, Yang D. 1985. The Nereididae (polychaetous nnelids) of the Chinese Coast. Beijing: China Ocean Press. p. 234.

Yan T, Yan W, Dong Y, Wang H, Yan Y, Liang G. 2006. Marine fouling of offshore installations in the northern Beibu Gulf of China. International Biodeterioration \& Biodegradation 58:99-105.
Yan T, Yan WX, Dong Y, Wang HJ, Yan Y, Liang GH. 2009. Marine fouling on floating installations west of Dongsha Islands, the northern South China Sea. International Biodeterioration \& Biodegradation 63:1079-1087.

Zenetos A, Cinar ME, Pancucci-Papadopoulou MA, Harmelin JG, Furnari G, Andaloro F, Bellou N, Streftaris N, Zibrowius H. 2005. Annotated list of marine alien species in the Mediterranean with records of the worst invasive species. Mediterranean Marine Science 6(2):63-118. 
